\title{
New corona virus: is just a tip of iceberg?
}

\section{Arvind Narwat*, Seema Rani, Garima Bhutani, Rahul Saini, Kamaldeep Singh}

\author{
Department of Pharmacology, B. P. S. Government Medical College for Women, Khanpur Kalan, Sonipat Haryana, \\ India
}

\author{
Received: 21 April 2020 \\ Revised: 15 May 2020 \\ Accepted: 20 May 2020 \\ *Correspondence: \\ Dr. Arvind Narwat, \\ Email: arvindnarwat16@gmail.com
}

Copyright: () the author(s), publisher and licensee Medip Academy. This is an open-access article distributed under the terms of the Creative Commons Attribution Non-Commercial License, which permits unrestricted non-commercial use, distribution, and reproduction in any medium, provided the original work is properly cited.

\begin{abstract}
The world is again experiencing a global viral epidemic of zoonotic origin. As of March 30, 785807 confirmed cases of coronavirus disease 2019 (COVID-19) and 37820 deaths had been reported in more than 120 countries. Strenuous efforts are being made by various countries of the world to halt transmission through shutting down transport, quarantining entire cities and enforcing the use of face masks. International flights have been cancelled and affected cruise ships quarantined. As in all outbreaks, there is an urgent need to develop effective diagnostics, therapeutics and vaccines. Several experimental diagnostic platforms are already in use in China and elsewhere. The whole-genome sequence of SARS-CoV-2 has been obtained and shared widely. Several potential treatments have been proposed, however, no antiviral treatment has been approved for the novel coronavirus, and despite two outbreaks of novel coronaviruses in the past two decades, vaccine development is still in its infancy.
\end{abstract}

Keywords: Antiviral, COVID-19, New corona virus, SARS-CoV-2

\section{INTRODUCTION}

To date, there is still a variety of human diseases with unknown etiology. A viral origin has been suggested for many of these diseases, emphasizing the importance of a continuous search for new viruses. ${ }^{1-3}$ Coronaviruses were discovered in the early 1930s when an acute respiratory infection of domesticated chickens was shown to be caused by a virus now known as avian infectious bronchitis virus (IBV). The first human coronaviruses $(\mathrm{HCoV})$ were discovered in the 1960s. The name "coronavirus," coined in 1968, is derived from the "corona"-like or crown-like morphology observed for these viruses in the electron microscope. ${ }^{4}$ In 1975, the coronaviridae family was established by the International committee on the taxonomy of viruses. Until the emergence of SARS in 2003, only two, HCoV 229E and OC43, were recognized as human pathogens. Both were causes of the common cold, considered a mild and insignificant illness and thus not a high priority for intensive research. Following the recognition that SARS was caused by a novel coronavirus, two others new HCoVs, NL63 and HKU-1, were found in association with respiratory disease. The renewed interest in this group of viruses has led to the discovery of a plethora of other animal coronaviruses in diverse species and stimulated research on their capacity to cross speciesbarriers to infect new animal species.

\section{CLASSIFICATION}

Coronaviruses are classified into three groups, initially based on antigenic relationships of the spike (S), membrane $(\mathrm{M})$ and nucleocapsid $(\mathrm{N})$ proteins and now reenforced by viral genetic phylogeny. ${ }^{5}$

Group 1

- Human coronavirus (HCoV) 229E

- Human coronavirus NL63 
- Porcine transmissible gastro-enteritis virus (TGEV)

- Canine coronavirus $(\mathrm{CCoV})$

- Feline infectious peritonitis virus (FIPV)

- Porcine epidemic diarrhoea virus (PEDV)

- Bat coronaviruses (e.g. 1A, HKU2).

\section{Group 2}

- Human coronavirus (HCoV) OC43

- Human coronavirus HKU1

- SARS coronavirus (SARS-CoV-2: the novel coronavirus that causes coronavirus disease 2019, or COVID-19)

- Rat coronavirus (RCoV)

- Rat sialodacro-adenitis virus (SDAV)

- Porcine haemagglutinating encephalomyelitis virus (HEV)

- Bovine coronavirus (BCoV)

- Mouse hepatitis virus (MHV)

- Bat coronaviruses (e.g. SARS-like coronavirus Rp3, HKU4, 229E like bat coronavirus)

\section{Group 3}

- Avian infectious bronchitis virus (IBV)

- Turkey coronavirus (TcoV)

Coronaviruses have been identified in mice, rats, chickens, turkeys, swine, dogs, cats, rabbits, horses, cattle and humans, and can cause a variety of severe diseases including gastroenteritis and respiratory tract diseases. ${ }^{6,7}$ The recently identified SARS-CoV causes a lifethreatening pneumonia, and is the most pathogenic human coronavirus identified thus far. ${ }^{8}$ SARS-CoV is likely to reside in an animal reservoir, and has recently initiated the epidemic in humans through zoonotic transmission. ${ }^{9,10}$ In December 2019, this novel corona virus was identified as a cause of upper and lower respiratory tract infections in Wuhan, a city in the Hubei Province of China. It rapidly spread, resulting in an epidemic throughout China and then gradually spreading to other parts of the world in pandemic proportions. It has affected almost every continent in this world, except Antarctica. In February 2020, the World Health Organization designated the disease COVID-19, which stands for corona virus disease 2019. ${ }^{11}$

\section{TRANSMISSION}

Till now understanding of the mode of transmission is currently incomplete. Epidemiologic investigation in Wuhan at the beginning of the outbreak identified an initial association with a seafood market where most patients had worked or visited. ${ }^{12}$ The seafood market also sold live rabbits, snakes and other animals. The initial concept was that the virus originated from snakes, however later studies proved that it had more similarity with bat-borne viruses. However, as the outbreak progressed, person-to-person transmission through droplets and fomites became the primary mode of transmission. It may be possible that a person can get COVID-19 by touching a surface or object that has the virus adhering to it and then touching their own mouth, nose or possibly their eyes. But this is not thought to be the main mode of transmission of the virus. In February, a Chinese new-born was diagnosed with the new coronavirus just 30 hours after birth. The baby's mother tested positive before she gave birth. It is unclear how the disease was transmitted - in the womb, or after birth. ${ }^{13}$ Recently in London another new-born was tested positive for the coronavirus, marking what appears to be the second such case as the pandemic worsens. ${ }^{14}$ The exact incubation period is not known. It is presumed to be between 2 to 14 days after exposure, with most cases occurring within 5 days after exposure. ${ }^{15,16}$

\section{CLINICAL PRESENTATION}

According to a study describing 1099 patients with COVID-19 pneumonia in Wuhan, the most common clinical features at the onset of illness were fever in $88 \%$, fatigue in $38 \%$, dry cough in $67 \%$, myalgias in $14.9 \%$, dyspnea in $18.7 \% .^{16}$

Pneumonia appears to be the most common and severe manifestation of infection. In this group of patients breathing difficulty developed after a median of five days of illness. Acute respiratory distress syndrome developed in $3.4 \%$ of patients. Other symptoms were headache, sore throat, rhinorrhea, gastrointestinal symptoms and loss of sense of smell and taste.

\section{Diagnosis case definition (as per WHO-China joint commission report) ${ }^{17}$}

\section{Suspected case}

Based on the epidemiologic characteristics observed so far in China, everyone is assumed to be susceptible, although there may be risk factors increasing susceptibility to infection.

A patient with acute respiratory tract infection (sudden onset of at least one of the following: cough, fever, shortness of breath) and with no other aetiology that fully explains the clinical presentation and with a history of travel or residence in a country/area reporting local or community transmission during the 14 days prior to symptom onset.

A patient with any acute respiratory illness and having been in close contact with a confirmed or probable COVID-19 case in the last 14 days prior to onset of symptoms; or a patient with severe acute respiratory infection (fever and at least one sign or symptom of respiratory disease (e.g., cough, fever, shortness breath) and requiring hospitalization (SARI) and with no other aetiology that fully explains the clinical presentation. 


\section{Probable case}

A suspected case for whom testing for virus causing COVID-19 is inconclusive (according to the test results reported by the laboratory) or for whom testing was positive on a pan-coronavirus assay.

\section{Confirmed case}

A person with laboratory confirmation of virus causing COVID-19 infection, irrespective of clinical signs and symptoms.

\section{Close contacts}

Close contact of a probable or confirmed case is defined as a person living in the same household as a COVID-19 case, a person having had direct physical contact with a COVID-19 case (e.g. shaking hands), a person having unprotected direct contact with infectious secretions of a COVID-19, case (e.g. being coughed on, touching used paper tissues with a bare hand), a person having had faceto-face contact with a COVID-19 case within 2 metres and $>15$ minutes, a person who was in a closed environment (e.g. classroom, meeting room, hospital waiting room, etc.) with a COVID-19 case for 15 minutes or more and at a distance of less than 2 metres. A healthcare worker $(\mathrm{HCW})$ or other person providing direct care for a COVID-19 case, or laboratory workers handling specimens from a COVID-19 case without recommended personal protective equipment (PPE) or with a possible breach of PPE, a contact in an aircraft sitting within two seats (in any direction) of the COVID-19 case, travel companions or persons providing care, and crew members serving in the section of the aircraft where the index case was seated (if severity of symptoms or movement of the case indicate more extensive exposure, passengers seated in the entire section or all passengers on the aircraft may be considered close contacts).

\section{Laboratory test ${ }^{17}$}

SARS-CoV-2 RNA is detected by polymerase chain reaction (RT-PCR). Results are generally available within a few hours to 2 days. A single positive test should be confirmed by a second RT-PCR assay targeting a different SARS-CoV-2 gene. If initial testing is negative but the suspicion for COVID-19 remains, the WHO recommends re-sampling and testing from multiple respiratory tract sites. For safety reasons, specimens from a patient with suspected or documented COVID-19 should not be submitted for viral culture. Samples should also be tested for other viral/bacterial pathogens.

\section{COVID 19- rapid tests}

COVID-19 rapid test qualitatively detects IgG and IgM antibodies to SARS-CoV-2 in human whole blood, serum and plasma samples. This test applies lateral flow immuno-chromatography and is a tool to assist in the diagnosis of SARS-CoV-2 infections. The IgM-IgG combined assay has better utility and sensitivity compared with a single IgM or IgG test. It can be used for the rapid screening of SARS-CoV-2 carriers, symptomatic or asymptomatic, in hospitals, clinics, and test laboratories.

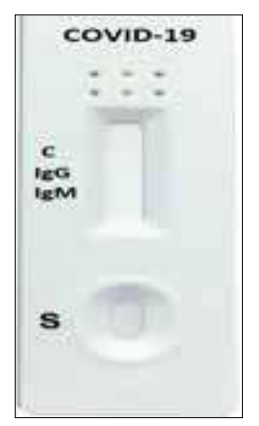

Figure 1: COVID-19 rapid test kit.

\section{Management}

At the moment, the therapeutic strategies to deal with the infection are only supportive, and prevention aimed at reducing transmission in the community is our best weapon.

\section{WHO all needs isolation or criteria for isolation}

Any person diagnosed with SARS-CoV-2 infection by means of laboratory testing at a government recommended testing laboratory. Anyone who has symptoms of fever and respiratory illness, and has a history of close contact of a person who has either been diagnosed as COVID-19, or has a history of travel to a COVID affected region within the last 14 days. Any health care worker with symptoms of fever and respiratory illness who has been involved directly in treating COVID-19 patients, or has close contact with persons involved in treating COVID-19 patients during the last 14 days.

\section{Treatment}

There is no specific antiviral treatment recommended for COVID-19, and no vaccine is currently available at time of writing this article. ${ }^{18}$

\section{Mild disease}

These patients usually present with symptoms of An upper respiratory tract viral infection, low grade fever, cough, malaise, rhinorrhoea, sore throat without any warning signs, shortness of breath, hemoptysis, gastrointestinal symptoms: nausea, vomiting, diarrhoea, without change in mental status (i.e., confusion, lethargy), non immunocompromised.

\section{Recommendation}

Consider for home isolation in asymptomatic/mild disease. 
Table 1: Summary of currently available drugs which can be potentially used for treatment of COVID-19 disclaimer, the options listed below are not licensed for the treatment of COVID-19. ${ }^{18}$

\begin{tabular}{|c|c|c|c|c|}
\hline Agent & Classification & Mechanism of action & Dosage & Side effects \\
\hline Hydroxychloroquine & Off label use & $\begin{array}{l}\text { Hampers low PH } \\
\text { dependant steps of } \\
\text { viral replication }\end{array}$ & $\begin{array}{l}400 \mathrm{mg} \text { BID } \times 2 \\
\text { doses, then } 200 \mathrm{mg} \\
\text { BID for } 5 \text { days }\end{array}$ & $\begin{array}{l}\text { QT } \\
\text { prolongation }\end{array}$ \\
\hline Oseltamivir & $\begin{array}{l}\text { No trials on } \\
\text { COVID-19 }\end{array}$ & $\begin{array}{l}\text { Neuraminidase } \\
\text { enzyme inhibitor in } \\
\text { influenza }\end{array}$ & $\begin{array}{l}150 \mathrm{mg} \text { BID } \\
\text { for } 5 \text { days }\end{array}$ & $\begin{array}{l}\text { GI intolerance } \\
\text { headache insomnia }\end{array}$ \\
\hline Remdesivir & $\begin{array}{l}\text { Investigational } \\
\text { (can be used only } \\
\text { on compassionate } \\
\text { basis) }\end{array}$ & $\begin{array}{l}\text { RNA dependent RNA } \\
\text { polymerase inhibitor }\end{array}$ & $\begin{array}{l}200 \mathrm{mg} \text { IV loading } \\
\text { dose, then } 100 \mathrm{mg} \text { IV } \\
\text { daily, up to10 days }\end{array}$ & $\begin{array}{l}\text { GI intolerance } \\
\text { hepatotoxicity }\end{array}$ \\
\hline Lopinavir/ritonavir & Off label use & $\begin{array}{l}\text { 3CLpro (viral } \\
\text { protease) inhibitor }\end{array}$ & $\begin{array}{l}400 / 100 \mathrm{mg} \text { BID for } \\
\text { up to } 10 \text { days }\end{array}$ & $\begin{array}{l}\text { QT prolongation } \\
\text { hepatotoxicity }\end{array}$ \\
\hline Ribavirin & Off label use & $\begin{array}{l}\text { Inhibitor of RNA } \\
\text { polymerization }\end{array}$ & $\begin{array}{l}2 \text { grams (loading } \\
\text { dose) then } 600 \mathrm{mg} \\
\text { TID }\end{array}$ & $\begin{array}{l}\text { High risk of toxicity } \\
\text { boxed warning } \\
\text { for haemolyticanaemia }\end{array}$ \\
\hline Interferon beta B1 & Off label use & $\begin{array}{l}\text { Immunomodulatory; } \\
\text { enhancement of innate } \\
\text { and adaptive viral } \\
\text { immunity }\end{array}$ & & $\begin{array}{l}\text { Flu like syndrome } \\
\text { depression }\end{array}$ \\
\hline Tocilizumab & Off label use & $\begin{array}{l}\text { Monoclonal antibody } \\
\text { to IL6 receptor / treats } \\
\text { cytokine release } \\
\text { syndrome }\end{array}$ & & $\begin{array}{l}\text { Elevation of liver } \\
\text { enzymes increased } \\
\text { risk of re-activation } \\
\text { of other respiratory } \\
\text { infections }\end{array}$ \\
\hline $\begin{array}{l}\text { Antibiotics } \\
\text { (broad spectrum) }\end{array}$ & $\begin{array}{l}\text { Initiate as per } \\
\text { institution-based } \\
\text { CAP/VAP policy }\end{array}$ & $\begin{array}{l}\text { Secondary bacterial } \\
\text { infection (CAP)/VAP }\end{array}$ & - & - \\
\hline Corticosteroids & \multicolumn{4}{|c|}{$\begin{array}{l}\text { Not indicated in treating SARS-CoV-2 as per available evidence. Might prolong viral } \\
\text { shedding. Use as per indicated in septic shock/if patient has other indications for steroid use }\end{array}$} \\
\hline $\begin{array}{l}\text { IV immunoglobulin } \\
\text { (IVIG) }\end{array}$ & Off label use & $\begin{array}{l}\text { Antibodies from } \\
\text { convalescent plasma } \\
\text { might suppress viraemia. } \\
\text { Theoretically: better to } \\
\text { start at early stage of } \\
\text { disease }\end{array}$ & $\begin{array}{l}\text { Consider IVIG at } \\
\text { standard dose of } \\
1 \mathrm{gm} / \mathrm{kg} \\
\text { daily } \times 2 \text { doses }\end{array}$ & $\begin{array}{l}\text { Might interact with } \\
\text { antivirals/ }\end{array}$ \\
\hline
\end{tabular}

Table 2: COVID-19 management in a nut shell, there are no PROVEN or APPROVED treatments for COVID-19. ${ }^{18}$

\begin{tabular}{|c|c|}
\hline Severity of illness & Plan \\
\hline Mild illness: without any risk factors/co-morbidities & $\begin{array}{l}\text { - Outpatient care } \\
\text { - Strict home quarantine monitored by government/ } \\
\text { health authorities } \\
\text { - Supportive care } \\
\text { - Assess patient's clinical condition via telephonic } \\
\text { conversation/ using telemedicine facility }\end{array}$ \\
\hline $\begin{array}{l}\text { Moderate illness: } \\
\text { - } \quad \text { Dyspnea } \\
\text { - } \quad \text { Hypoxemia } \\
\text { - } \quad \text { Infiltrates/consolidation on chest x-ray/ CT scan }\end{array}$ & $\begin{array}{l}\text { - Admit in hospital isolation room } \\
\text { - Supportive care } \\
\text { - Start empirical antibiotics as per local community } \\
\text { acquired pneumonia treatment guidelines } \\
\text { - Oseltamivir } 75 / 150 \mathrm{mg} \mathrm{BD} \\
\text { - Consider starting hydroxychloroquine or } \\
\text { lopinavir/ritonavir (If evident risk factors for } \\
\text { progression of disease are present) }\end{array}$ \\
\hline
\end{tabular}




\begin{tabular}{|c|c|}
\hline Severity of illness & Plan \\
\hline $\begin{array}{l}\text { Critical illness: } \\
\text { - Mechanically ventilated patient's } \\
\text { - Multi lobar/ bilateral lung consolidation } \\
\text { Careful using these drugs in patients with multi-organ } \\
\text { damage }\end{array}$ & $\begin{array}{l}\text { - Remdesivir (for compassionate use only) } \\
\text { - Tocilizumab can be considered (check IL-6 level prior } \\
\text { to starting tocilizumab). Especially in patients with } \\
\text { evidence of cytokine release syndrome. } \\
\text { - Continue IV antibiotics and supportive care } \\
\text { - Rule out ventilator associated pneumonia/ catheter } \\
\text { related infections and other secondary } \\
\text { bacterial/viral/fungal infections } \\
\text { - Always keep in mind the to rule out differentials of non- } \\
\text { resolving pneumonia } \\
\text { In ventilated patients: follow ARDS NET protocol } \\
\text { - Consider ECMO if need arises } \\
\text { - Refractory or progressive cases in ICU: interfere on } \\
\text { beta B1 can be considered. However, it should be } \\
\text { combined with an anti-viral (lopinavir/ritonavir) and } \\
\text { hydroxychloroquine }\end{array}$ \\
\hline
\end{tabular}

\section{Prevention}

Various health authorities all over the world have emphasized on prevention of community spread of the virus. Measures commonly suggested by them are social distancing (at least six feet); maintain hygiene (wash hands regularly and avoid touching face, nose, mouth and eyes); regular use of alcohol-based hand sanitizers (containing at least $60 \%$ of alcohol).

\section{DISCUSSION}

The recently identified SARS-CoV causes a lifethreatening pneumonia, and is the most pathogenic human coronavirus identified thus far. ${ }^{8}$ SARS-CoV is likely to reside in an animal reservoir, and has recently initiated the epidemic in humans through zoonotic transmission. ${ }^{9,10}$ In December 2019, this novel corona virus was identified as a cause of upper and lower respiratory tract infections in Wuhan, a city in the Hubei Province of China. It rapidly spread, resulting in an epidemic throughout China and then gradually spreading to other parts of the world in pandemic proportions. It has affected almost every continent in this world, except Antarctica. In February 2020, the World Health Organization designated the disease COVID-19, which stands for corona virus disease 2019. ${ }^{11}$ Several potential treatments have been proposed, however, no antiviral treatment has been approved for the novel coronavirus, and despite two outbreaks of novel coronaviruses in the past two decades, vaccine development is still in its infancy.

\section{CONCLUSION}

Corona virus disease 2019 (COVID-19) was reported as cluster of disease in China in December 2019. It has since spread to all continents except antarctica and WHO declared COVID-19 as a pandemic. Efforts by the world to halt transmission through shutting down transport, quarantining entire cities and enforcing the use of face masks. International flights have been cancelled and affected cruise ships quarantined. Elderly persons with co-morbidities are more affected and it spreads mainly via respiratory droplets. Pneumonia is the most common complication. As in all outbreaks, there is an urgent need to develop effective diagnostics, therapeutics, and vaccines but presently there is no approved treatment or vaccine available for COVID-19 and prevention is the best option.

\section{Funding: No funding sources \\ Conflict of interest: None declared \\ Ethical approval: Not required}

\section{REFERENCES}

1. Stohlman SA, Hinton DR. Viral induced demyelination. Brain Pathol. 2001;1:92-106.

2. Jubelt B, Berger JR. Does viral disease underlie ALS? Lessons from the AIDS pandemic. Neurol. 2001;57(6):945-6.

3. Shingadia D, Bose A, Booy R. Could a herpesvirus be the cause of Kawasaki disease? Lancet Infect Dis. 2002;2(5):310-3.

4. Tyrrel DAJ, Almedia JD, Berry DM, Cunningham $\mathrm{CH}$, Hamre D, Hofstad MS, et al. Coronavirus. Nature. 1968;220:650.

5. Peiris JSM, Coronaviruses. In: Douglas DR, Richard JW, Frederick GH, editors. Clincal Virology. $4^{\text {th }}$ ed. Washington DC: ASM Press; 2017:587-593.

6. Holmes KV, Lai MMC. Coronaviridae. In: Fields BN, editor. Fields Virology. $3^{\text {rd }}$ ed. Philadelphia: Lippincott-Raven Publishers; 1995:1075-1093.

7. Guy JS, Breslin JJ, Breuhaus B, Vivrette S, Smith LG. Characterization of a coronavirus isolated from a diarrheic foal. J Clin Microbiol. 2000;38(12):4523-6.

8. Peiris JS, Chu CM, Cheng VC, Chan KS, Hung IF, Poon LL, et al. Clinical progression and viral load in a community outbreak of coronavirus-associated 
SARS pneumonia: a prospective study. Lancet. 2003;361(9371):1767-72.

9. Martina BE, Haagmans BL, Kuiken T, Fouchier RA, Rimmelzwaan GF, Van Amerongen G, et al. Virology: SARS virus infection of cats and ferrets. Nature. 2003;425(6961):915.

10. Guan Y, Zheng BJ, He YQ, Liu XL, Zhuang ZX, Cheung CL, et al. Isolation and characterization of viruses related to the SARS coronavirus from animals in southern China. Sci. 2003;302(5643):276-8.

11. World Health Organization. Director-General's remarks at the media briefing on 2019-nCoV. 2020. Available at: https://www.who.int/dg/speeches/ detail/who-director-general-s-remarks-at-the-mediabriefing-on-2019-ncov-on-11-february-2020. Accessed on $15^{\text {th }}$ February 2020.

12. World Health Organization. Novel coronavirus situation report-2, 2020. Available at: https://www. who.int/docs/default-source/corona viruse/situationreports/20200122-sitrep-2-2019-ncov.pdf. Accessed on $23^{\text {rd }}$ January 2020.

13. British broadcasting corporation. Coronavirus: Newborn becomes youngest person diagnosed with virus, 2020. Available at: https://www.bbc.com/ news/world-asia-china-51395655. Accessed on $7^{\text {th }}$ February 2020.

14. New York post. Second newborn baby tests positive for coronavirus, 2020. Available at: https://nypost. com/2020/03/13/second-newborn-baby-testspositive-for-coronavirus/. Accessed on $15^{\text {th }}$ March 2020.

15. Li Q, Guan X, Wu P, Wang X, Zhou L, Tong Y, et al. Early transmission dynamics in Wuhan, China, of novel coronavirus-infected pneumonia. $\mathrm{N}$ Engl J Med. 2020;382(13):1199-207.

16. Guan WJ, Ni ZY, Hu Y, Liang WH, Ou CQ, He JX et al. Clinical characteristics of coronavirus disease 2019 in China. N Engl J Med. 2020;382(18):1708-20.

17. World Health Organization. Report of the WHOChina Joint Mission on Coronavirus Disease 2019 (COVID-19), 2020. Available at: https://www.who. int/docs/default-source/corona viruse/who-chinajoint-mission-on-covid-19-final-report.pdf. Accessed on $15^{\text {th }}$ March 2020.

18. Bouadma L, Lescure FX, Lucet JC, Yazdanpanah Y, Timsit JF. Severe SARS-CoV-2 infections: practical considerations and management strategy for intensivists. Intensive Care Med. 2020;46(4):579-82.

Cite this article as: Narwat A, Rani S, Bhutani G, Saini R, Singh K. New corona virus: is just a tip of iceberg?. Int J Basic Clin Pharmacol 2020;9:114752 . 